\title{
Histopathological alterations in Astyanax bifasciatus (Teleostei: Characidae) correlated with land uses of surroundings of streams
}

\author{
Jardel Nimet $^{1}$, João Paulo de Arruda Amorim² and Rosilene Luciana Delariva ${ }^{1,2}$
}

This study evaluated gills and liver of Astyanax bifasciatus as histological biomarkers for biomonitoring of streams along areas with different land uses. The fish were collected by electrofishing in six streams in the basin of the lower Iguaçu River. The objective was to correlate the presence and degree of histopathological alterations of gills and liver with the environmental variables among streams along different land uses. The low frequency of histopathological alterations found in fish from the forest streams suggested normal organ functioning. In fish from the rural and urban streams, the histopathological alterations occurred were in higher frequency, indicated light to moderate damage in gills and liver of fish from the rural streams, and moderate to severe damage in liver of fish from urban streams. The histopathological alterations in gills (lamellar aneurysm) and livers (vascular congestion) verified in impacted streams were significantly more frequent and severe. It was possible to distinguish streams along different land uses, suggesting that these histopathological alterations can be used as biomarkers for biomonitoring studies. The health integrity of fish from streams in forest areas further reinforces the importance of maintaining preservation areas in basins under intensive land use.

Keywords: Biomarkers, Fish, Histopathology, Lotic environments, Urban impact.

Esse estudo avaliou brânquias e fígado de Astyanax bifasciatus como biomarcadores histológicos para biomonitoramento de riachos em áreas com diferentes usos do solo. Os peixes foram coletados por pesca elétrica em seis riachos na bacia do baixo rio Iguaçu. $\mathrm{O}$ objetivo foi correlacionar a presença e o grau de alterações histopatológicas em brânquias e fígado com as variáveis ambientais entre riachos com diferentes usos do solo. A baixa frequência de alterações histopatológicas encontradas em peixes de riachos florestados indicou funcionamento normal do órgão. Em peixes de riachos rurais e urbanos, as alterações histopatológicas encontradas foram em maior frequência, indicando danos leves para moderados em brânquias e fígado de peixes dos riachos rurais, e danos moderados para severos em fígado de peixes de riachos urbanos. As alterações histopatológicas em brânquias (aneurisma lamelar) e fígados (congestão vascular) observadas nos riachos impactados foram significativamente mais frequentes e severas. Foi possível distinguir os riachos com diferente uso do solo, sugerindo que estas alterações histopatológicas podem ser usadas como biomarcadores para estudos de biomonitoramento. A integridade da saúde dos peixes dos riachos nas áreas florestadas reforça ainda mais a importância de manter áreas de preservação nas bacias com intenso uso do solo.

Palavras-chave: Ambientes lóticos, Biomarcadores, Histopatologia, Impacto urbano, Peixe.

\section{Introduction}

The watersheds in Brazil are characterized by an immense network of small water courses, with different physiographic characteristics, which promotes the occurrence of a high diversity of organisms (Nogueira et al., 2010). However, a large part of these ecosystems is extremely threatened by the growing pollution caused by human activity (Miranda, 2012). The continuous contamination of these freshwater ecosystems by the release of urban, industrial, and agricultural pollutants has become a subject of great concern in recent decades (Ayadi et al., 2015).

In general, except for a few areas of the Amazon Region, all Brazilian basins are subjected to some of the main impacts on the freshwater ecosystems, considered global, such as habitat destruction, pollution, flow modification, and introduction of non-native species (Agostinho et al., 2005). In this scenario, the south and southeast regions, on the basis of higher densities of population and economic development,

${ }^{1}$ Programa de Pós-graduação em Conservação e Manejo de Recursos Naturais, Universidade Estadual do Oeste do Paraná, Rua Universitária 2069, 85819-110 Cascavel, PR, Brazil. (JN) jardelnimet@gmail.com, ○https://orcid.org/0000-0001-6358-2421 (corresponding author), (RLD) rosilene.delariva@unioeste.br

${ }^{2}$ Centro de Ciências Biológicas e da Saúde. Universidade Estadual do Oeste do Paraná, Rua Universitária 2069, 85819-110 Cascavel, PR, Brazil. amorimjpa@yahoo.com.br 
show high levels of impairment of water quality of their watersheds. An example of this situation is the Iguaçu River in Paraná State, considered the second most polluted river in Brazil (IBGE, 2015).

Despite being fundamental for the water supply of various cities and agricultural areas (Pereira, Scroccaro, 2010) as well as presenting high endemism of its fauna (Nogueira et al., 2010; Baumgartner et al., 2012), the Iguaçu River basin is highly impacted. At its higher and medium parts, the pollutants are derived mainly from urban and industrial sewage (Yamamoto et al., 2016), while in its lower part, the western part of the state, the principal contaminants are agricultural pesticides based on organophosphates and carbamates (Freire et al., 2015). In this sense, the biomonitoring of water bodies in order to assess environmental quality becomes extremely important, since these xenobiotics can pass by biotransformation in individuals or biomagnification in levels of the food web, thus compromising the entire ecosystem (Silva et al., 2013).

In biomonitoring studies, analysis of the bioindicator species can be performed through a group of biological responses, called biomarkers, which may determine the degree of impact on the health of the biota as well as identify the potential stressors responsible (van der Oost et al., 2003; Hauser-Davis et al., 2012). Bioindicators and biomarkers have been used to assess contamination of impacted areas (Paulino et al., 2014; Nimet et al., 2017).

The histological changes in fish tissue can be used as a tool to detect effects of chemical compounds on target organs (Freire et al., 2015). In this aspect, the gills, as they are in direct contact with the water, become an important histological biomarker of fishes exposed to contaminants (Gomes et al., 2012; Ayadi et al., 2015). In addition, the liver accumulates a number of toxic compounds (Troncoso et al., 2012) because of its role in the biotransformation of xenobiotics (Dane, Sisman, 2015). Thus, histological studies can provide predictive analyzes and information for water quality (van der Oost et al., 2003; Lins et al., 2010; Santos et al., 2012).

Astyanax bifasciatus Garavello, Sampaio, 2010 is a highly abundant, omnivorous teleost with wide distribution in the basin of the Iguaçu River (Baumgartner et al., 2012; Delariva et al., 2013). These features may reveal an intricate relationship with various levels of the food chain, which may indicate responses to chronic and cumulative effects. For this reason, this species is a potential bioindicator for biomonitoring studies in this basin. In this context, the present study started from the premise that the different land uses in the surroundings of the streams may influence the health condition of the fish. Thus, we tested the hypothesis that major changes occur in the tissues of gill and liver of Astyanax bifasciatus present in streams exposed to effluents from urban and rural areas. Hereby, the objectives of this study were: (I) to verify possible differences in environmental variables between streams with different land uses; (II) to assess the occurrence and frequency of histopathological alterations in gills and liver of $A$. bifasciatus in streams with different land uses; (III) to correlate the presence and degree of histopathology of gill and liver with environmental variables between the streams studied.

\section{Material and Methods}

Study area. Samplings were carried out in streams of $1^{\text {st }}$ to $3^{\text {rd }}$ orders (Strahler, 1957), which are inserted in the basins of tributary rivers of the lower Iguaçu River (Fig. 1). The choice and distribution of the streams followed the criterion that they do not have a connection between tributaries. Therefore, they were considered as sampling replicas (Gotelli, Ellison, 2011). The streams sampled were classified a priori in terms of the land use of the watersheds. The Google Earth Pro program was used to demarcation of the area of the watershed $\left(\mathrm{km}^{2}\right)$. Through the verification of the point in which the elevation of the terrain becomes to decay, were marked several points for the definition of a polygon from the area of the watershed and categorized them according to the following criteria: - Area with vegetation: remnants of forest and presence of riparian forest within the area of the watershed; - Rural area: defined by the presence of pastures, cropping land, and buildings; - Urbanized area: places of land waterproofing with buildings and industrial activities.

The streams were categorized according to the percentage of land occupation in: forest (considered as less impacted, presenting more than $50 \%$ of plant cover - This nomenclature is similar to the terms "reference" or "control" commonly used in the literature), rural (more than $50 \%$ of agricultural use), and urban (more than $25 \%$ of urban areas). The points and their geographic locations are described in Tab 1.

The areas characterized as rural comprise monoculture plantations, mainly of soybean and corn, and use various pesticides for pest control (IPARDES, 2013), whereas those considered as urban comprised small businesses and housing in cities (10 to 20 thousand inhabitants) (IBGE, 2014).

Physical and chemical water parameters. In all streams, we determined three measurements of each parameter in situ (water temperature, $\mathrm{pH}$, conductivity, turbidity, and dissolved oxygen), using a multi-parameter water quality monitoring probe - HORIBA, model U52-10, Japan.

Field procedures. Fish were collected by electrofishing technique with three paces of 40 minute in 50 meters length at each stream. The electrofishing equipment was powered by a portable generator (White, $2.5 \mathrm{~kW}, 220 \mathrm{~V}, 3-4 \mathrm{~A}$ ) connected to a DC transformer, with two electrified net rings (anode and cathode) (Output voltage varied from 400 to $600 \mathrm{~V})$. Sampling was performed under the SISBio license number 42565.

For each stream, 10 adult individuals of Astyanax bifasciatus were captured for histopathological analysis, except when the total abundance of the species was smaller. 


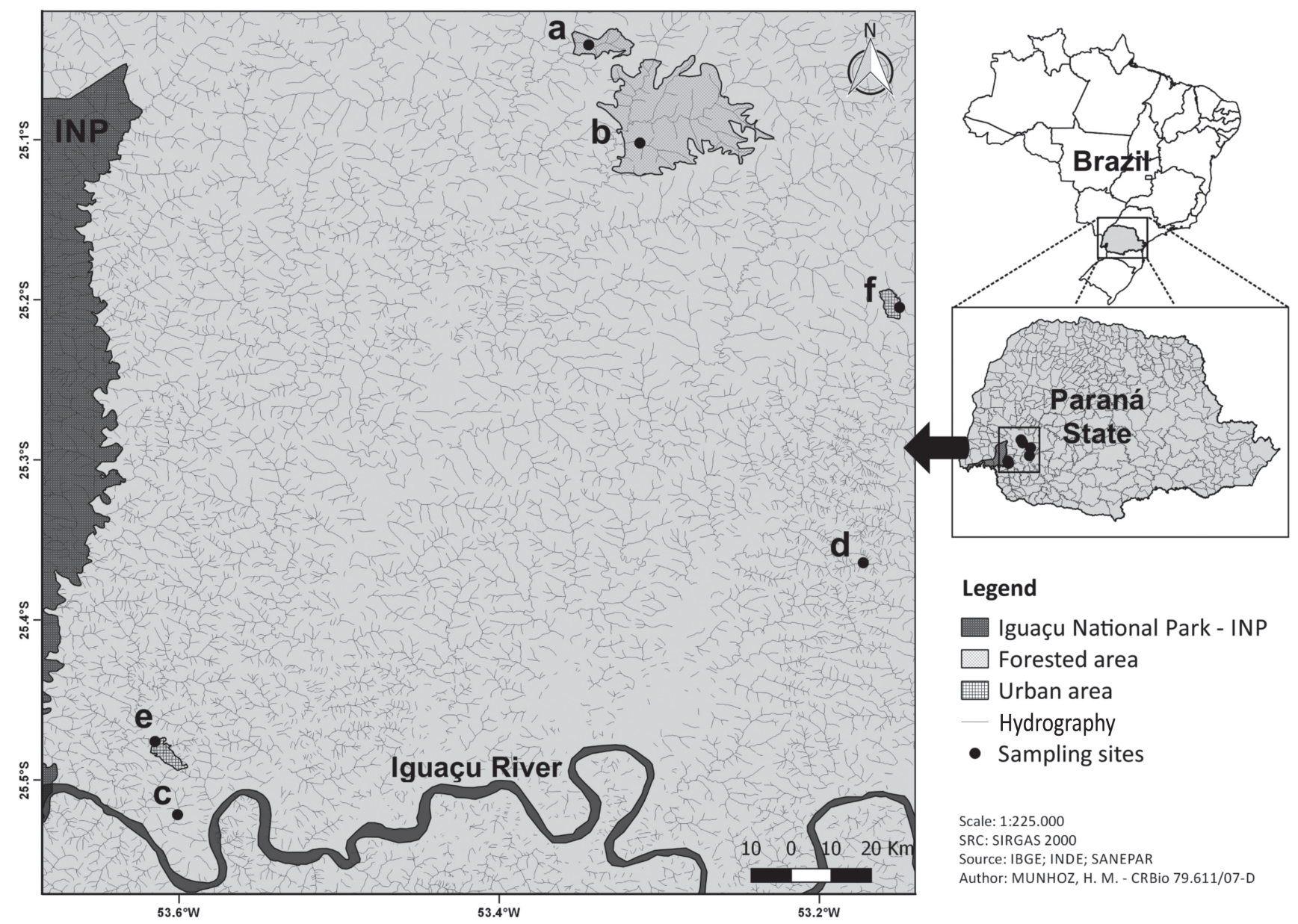

Fig. 1. Area of study highlighted from the hydrographic map of the State of Paraná. Letters indicate the sampled streams: a. F1 Forest area (Lajeado Stream); b. F2 Forest area (Pedregulho Stream); c. R1 rural area (Cacula Stream); d. R2 rural area (Avenca Stream); e. U1 urban area (Aparecida Stream); f. U2 urban area (Adelaide Stream).

Histological analysis. The collected fish were anesthetized with benzocaine diluted in water $(1: 80)$ and euthanized by spinal sectioning (in accordance with the Committee for Ethics in Animal Experimentation of UNIOESTE, Protocol number 02011). The individuals were measured (total lengths and total standard - $\mathrm{cm}$ ) and weighed $(\mathrm{g})$. Gills and liver were removed and fixed in ALFAC (alcohol $80 \%$, formaldehyde PA and acetic acid glacial PA - 85\%; $10 \%$ and approximately $5 \%$ ).

The gill and liver were dehydrated in ascending series of ethanol, cleared in xylene, and embedded in Paraplast ${ }^{\mathbb{Q}}$. We made semi-serial cuts in a longitudinal direction with a thickness of $5 \mu \mathrm{m}$. The obtained cuts were stained with hematoxylin (Harris) and Eosin (HE) and toluidine blue (TB). For histopathological analysis, the gill area observed under the microscope covered approximately 5-10 filaments/sample, 10 samples/stream. For liver, it was approximately $3 \mathrm{~mm}$ tissue/sample, 10 samples/stream.

The sections were observed using a BX61 Olympus microscope and the images were captured and analyzed using a digital video DP7 Olympus camera and DP Controller 3.2.1.276 software.

The histopathology were quantified in the gills and livers (five random microscopic examinations/section, three sections/sample and 10 samples/stream) according to the tissue specificity (Liver: being a massive organ was considered the entire focal area and was performed the analysis in objective 100x. Gill: for presenting spaces between the lamellae, only areas with tissue for analysis were considered and made in objective 40x). The incidence and distribution of lesions were assessed according to Paulino et al. (2014), based on the following criteria: 0 , absence of lesions (absence or lesions up to $10 \%$ of the analyzed tissue); $0+$, rarely present (occurrence of lesions in $11 \%$ to $25 \%$ of the analyzed tissue); +, present (occurrence of lesions in $26 \%$ to $50 \%$ of the analyzed tissue); ++, usual (occurrence of lesions in $51 \%$ to $75 \%$ of the analyzed tissue) and +++, very frequent lesions (occurrence of lesions in $76 \%$ to $100 \%$ of the analyzed tissue). 


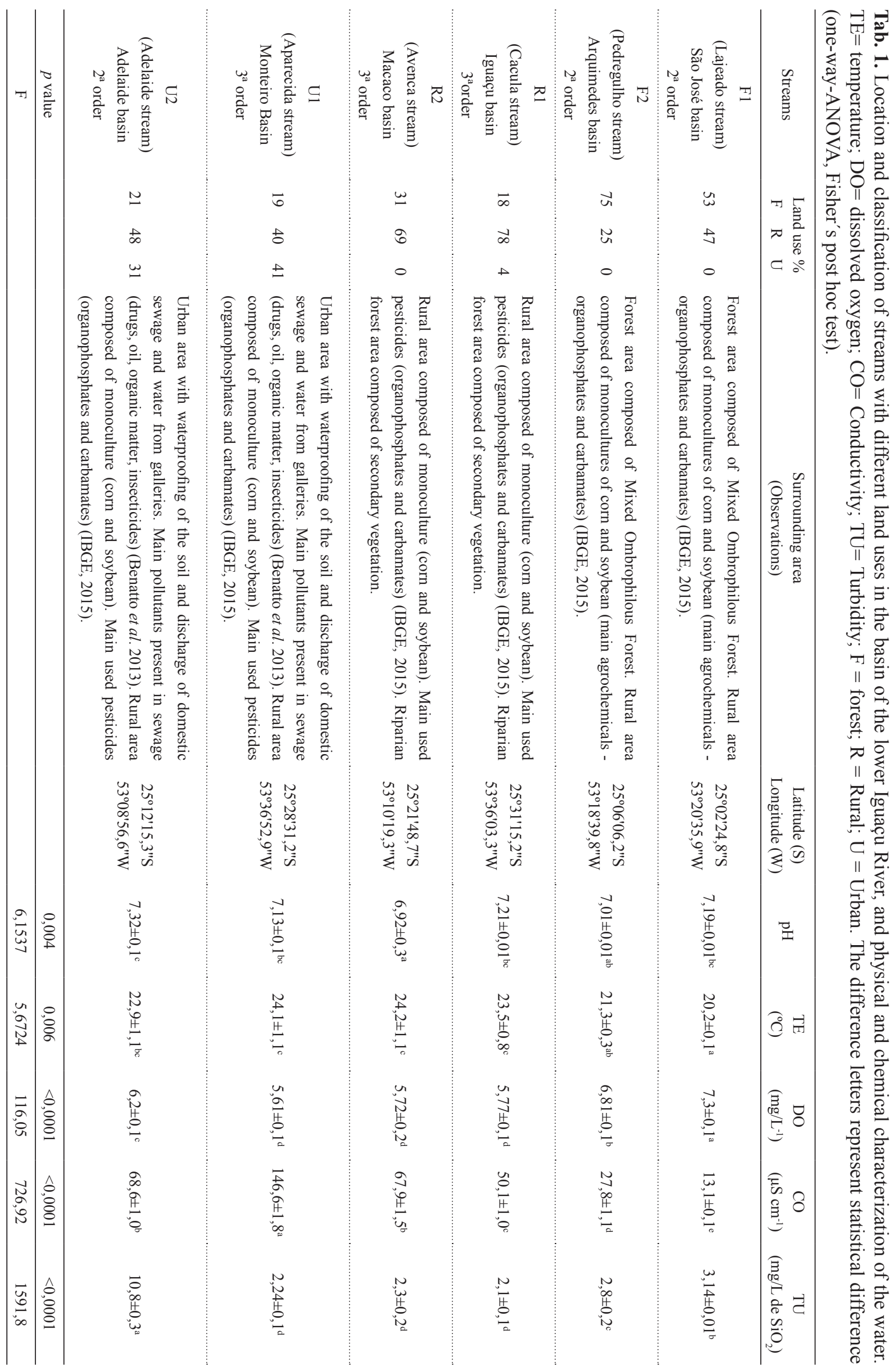


The presence of histopathological alterations to each component was evaluated semi-quantitatively (Poleksic, Mitrovic-Tutundzic, 1994; Montes et al., 2015) by the histopathologic index (HI), based on the type, location, and severity of lesions. The $\mathrm{HI}$ of gills $\left(\mathrm{HI}_{\mathrm{G}}\right)$ was calculated in accordance with Cerqueira, Fernandes (2002), modified from Poleksic, Mitrovic-Tutundzic (1994). The HI of the liver $\left(\mathrm{HI}_{\mathrm{L}}\right)$ was calculated according to Camargo, Martinez (2007). The histopathological alterations in each organ were classified into progressive stages (S) in the tissues: SI, histopathological alterations that do not alter the normal functioning of the tissue; SII, changes which are more severe and interfere with the functioning of the tissue; and stage SIII, very serious and irreparable damage. The HI was calculated from the types of lesion for each of the three stages and multiplied by the index of the stage, using the following equation proposed by Poleksic, MitrovicTutundzic (1994):

$$
\mathrm{I}=10^{0} \sum_{i=1}^{a} a i+10^{1} \sum_{i=1}^{b} b i+10^{2} \sum_{i=1}^{c} c i
$$

where $a=$ histopathological change of stage one (SI), $b=$ histopathological change of stage two (SII), and $c=$ histopathological change of stage three (SIII). An average index of fish sampled in each stream was calculated from the index obtained from each individual. Values of HI between 0 and 10 indicate normal operation of the organ, values between 11 and 20 indicate light to moderate damage to the organ, values between 21 and 50 indicate moderate to severe damage, values between 51 and 100 indicate severe lesions, and values above 100 indicate irreversible damage to the organ (Poleksic, Mitrovic-Tutundzic, 1994).

Data analysis. Statistical analyses were performed after evaluation of the assumptions of normality (Shapiro-Wilk test) and homoscedasticity (Levene's Test). To compare the physical and chemical variables between the streams, we conducted an analysis of single factor variance (ANOVA).

We performed nonparametric Kruskal-Wallis analysis to compare the histopathological index diagnosis (HI) of Astyanax bifasciatus in environments with different land uses, assuming a significance level of 0.05 . Subsequently, we performed post-hoc multiple comparison of the averages for all groups to verify possible differences among groups.

To summarize the relationship between the histopathology of gills and liver with the environmental variables in areas with different land uses, we performed the canonical correspondence analysis (CCA). In this analysis, the axes of ordination are linear combinations of environmental variables in gradient (streams) and the abundance (histopathological alterations), considered as answers to the gradient (Legendre, Legendre, 1998).

Kruskal-Wallis analysis was performed using STATISTICA 7.0 (Statsoft Inc 2004) and the CCA in the Past 2.14 program (Hammer et al., 2001).

\section{Results}

Physical and chemical water parameters. We found significant differences in the physical and chemical water parameters between the sampled streams $(p<0.05)$. Temperature, dissolved oxygen (DO), conductivity, and turbidity were those that most differentiated the groups of streams. The temperature was lower in forest streams; such streams also showed highest values of DO and lowest conductivity. The stream U2 had the highest turbidity (Tab. 1).

Histopathology in gills and liver. The general structure of the gills of Astyanax bifasciatus is formed by branchial arches arranged laterally in an oropharyngeal cavity protected by the operculum, where gas exchange occurs. The normal histological aspect of the gill is characterized by a central filament and pair of lateral lamellae (Fig. 2a). The most usual histopathological alterations registered in this study were lamellar oedema in fish of all streams (Fig. 2b). Lamellar aneurysm and mitochondria-rich cells (MRC) hyperplasia were frequent in fish of the rural and urban streams (Figs. 2c, h), followed by lamellar hyperplasia and mucous cells hyperplasia in fish from urban stream 2 (U2) (Figs. 2d, e, h). Partial fusion of lamellae and epithelium rupture and hemorrhage were observed in less than $10 \%$ of the fish in all the streams (Figs. 2f, g). Lower frequency of histopathological alterations was recorded in the gills of animals of the streams along forest areas. There was no focal necrosis, total fusion of lamellae, and lamellar hypertrophy in analyzed animals (Tab. 2). The histopathological index of gills $\left(\mathrm{HI}_{\mathrm{G}}\right)$ was substantially greater than 10 , only in fish of the rural and urban streams differing significantly from forest streams $(H=27.5, p<0.001)$.

The general aspect of the hepatic tissue of $A$. bifasciatus is constituted by a parenchyma which comprises hepatocytes arranged in a tubular pattern, forming a cord structure along the sinusoid vessels (Figs. 3a, b). The hepatic histopathological alterations most frequently observed were vascular congestion and cytoplasmic vacuolization, both in fish of the rural and urban streams (Fig. 3f). The greatest frequency of histopathological alterations was observed in fish from these streams, followed by the ones from rural areas. There was no focal necrosis in any analyzed fish (Tab. 2). We verified significant differences between the $\mathrm{HI}_{L}$ of forest streams when compared to the other streams $(\mathrm{H}=$ 21.3, $\mathrm{p}<0.001)$. The fishes of rural streams presented $\mathrm{HI}_{\mathrm{L}}$ values of 12 , indicating light to moderate damages to organs, while for the fishes of the urban streams it was of 27 , considered as moderate to severe tissue damage.

Relation between histopathology and environmental variables. Canonical correspondence analysis (CCA) summarized the metrics of biomarkers and their relations 
with the environmental variables, with accumulated variation of $75.11 \%$ for the first two canonic functions (CF) (Fig. 4). The first function (CF1) explained $43.62 \%$ of the variations $(p=0.026)$ and the second $(\mathrm{CF} 2)$ explained $31.49 \%(p=0.007)$. The forest streams were segregated from urban and rural streams along the first canonical function. The main environmental variables that resulted in this separation were dissolved oxygen (DO) and percentage area with vegetation $(\% \mathrm{~V})$ with positive scores. Temperature (TE), conductivity (CO), and percentage of urban area $(\% \mathrm{U})$, segregating the negative side, together with the highest values of frequency of histopathological alterations and considered more severe (stage II).
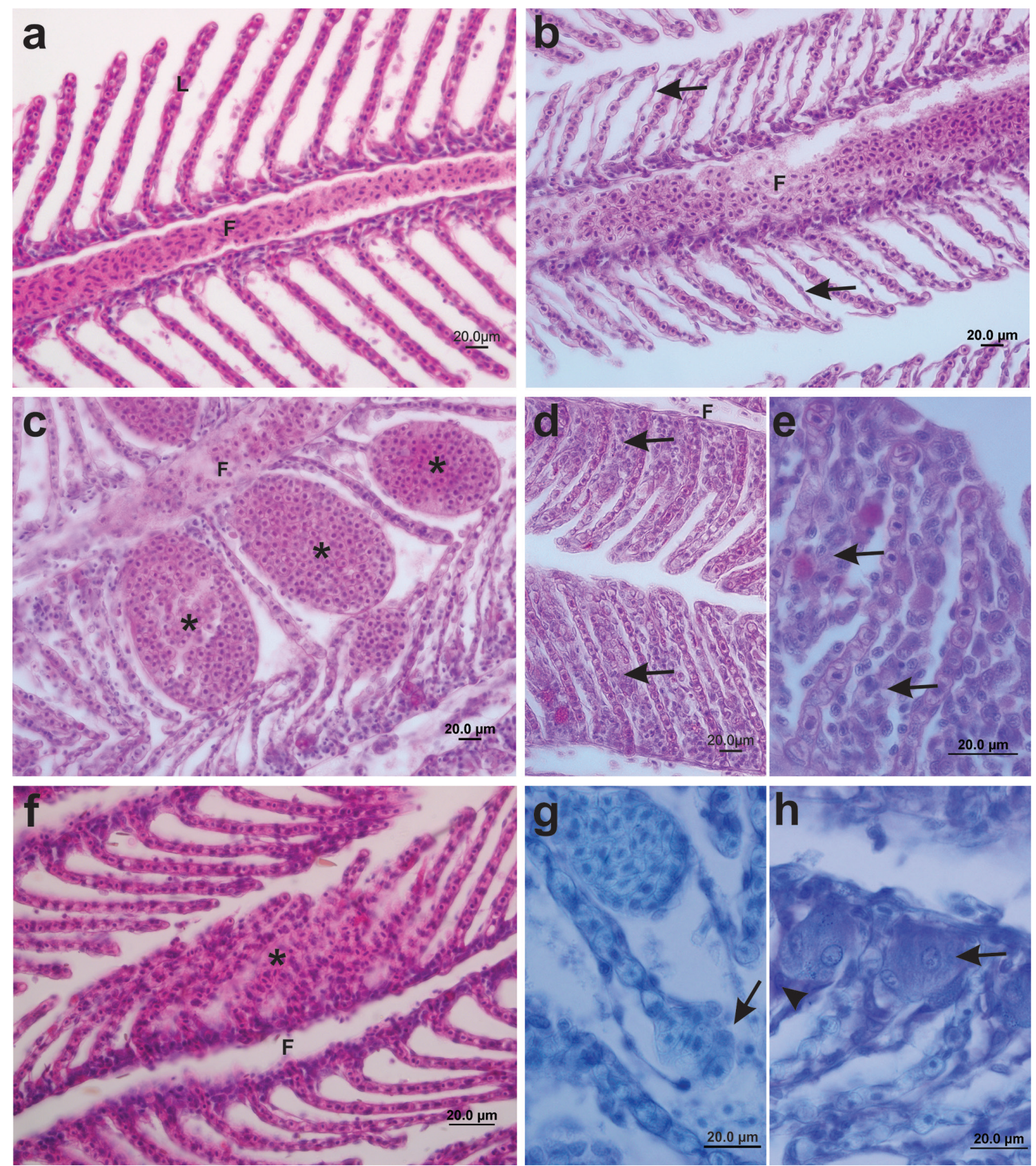

Fig. 2. Photomicrograph of gills of Astyanax bifasciatus from streams of the basin of the lower Iguaçu River. a. Normal aspect of gill in forest stream (F1), $F$ - filament, $L$ - lamellae. b. Lamellar oedema (arrows) in forest stream (F2). c. Lamellar aneurysm (*) in urban stream (U1). d. Lamellar hyperplasia (arrows) in rural stream (R2). e. Lamellar hyperplasia (arrows) in highest magnification in rural stream (R2). f. Partial fusion of lamellae (*) in rural stream (R1). g. Epithelium rupture and hemorrhage (arrow) in urban stream (U2). h. Mitochondria-rich cells hyperplasia (arrow) and mucous cells hyperplasia (head of arrow) in urban stream (U2). a-g. Stained Hematoxylin Harris and eosin. h. Stained toluidine blue. 


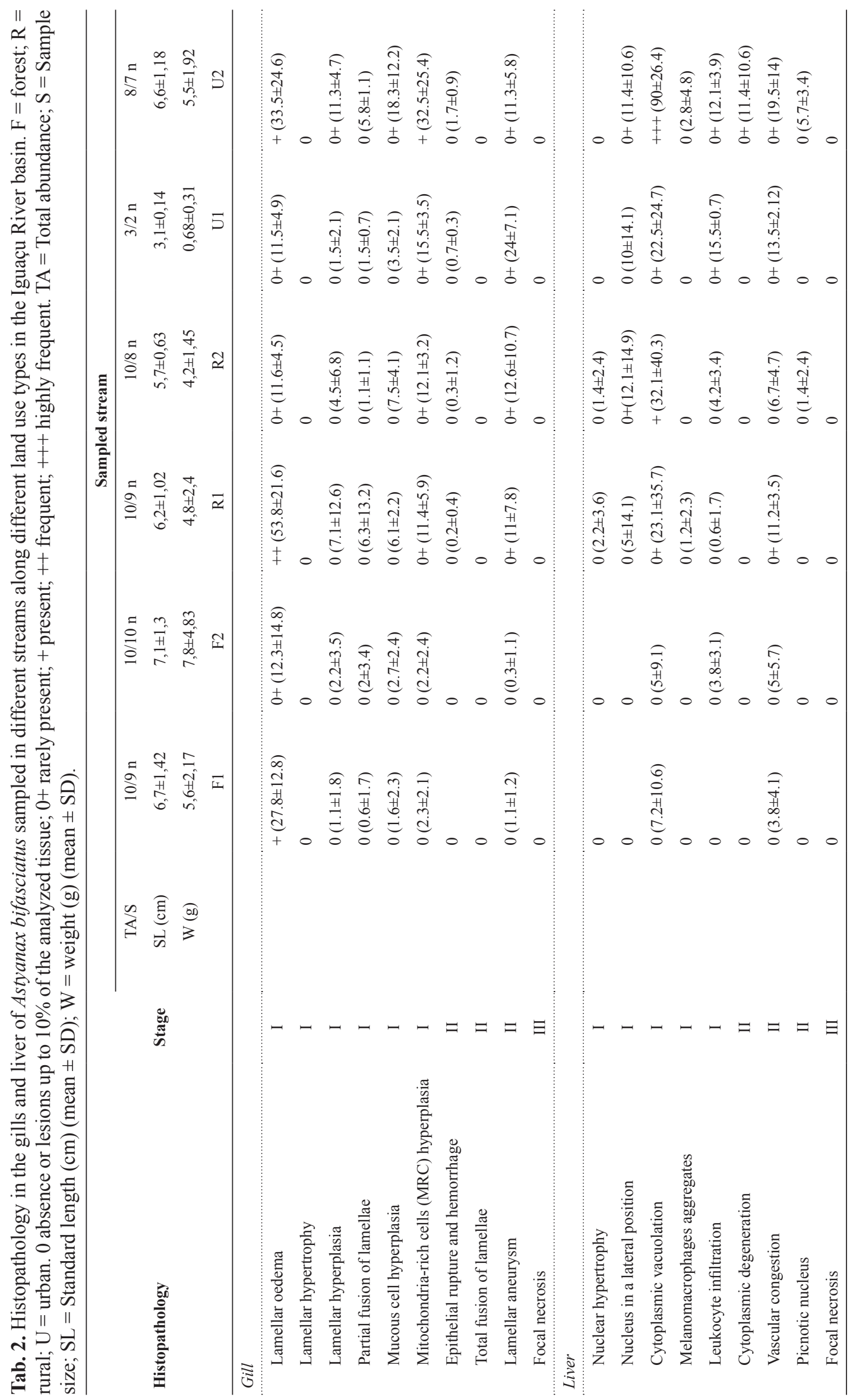



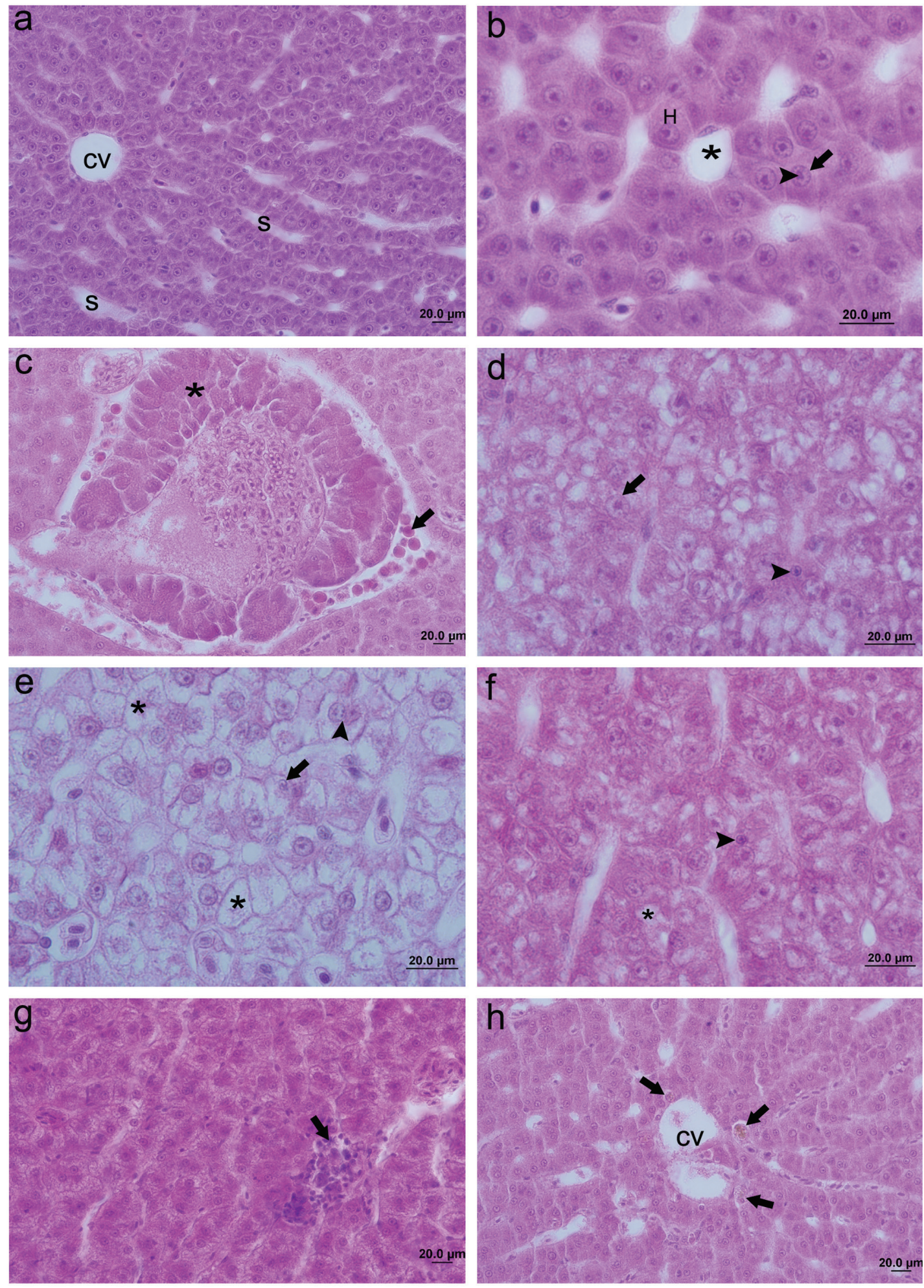

Fig. 3. Photomicrograph of liver of Astyanax bifasciatus in streams of the basin of the lower Iguaçu River. a. Normal liver, central vein (CV), and sinusoids capillary (S) in forest stream (F1). b. Tubular arrangement of hepatocytes $(\mathrm{H})$, nucleus (arrow), nucleolus (head of arrow), and centrilobular vein $(*)$ in forest stream (F1); c. Pancreatic tissue $(*)$, presence of eosinophils around the hepatopancreas tissue (arrow) in forest stream (F2). d. Presence of picnotic nucleus (head of arrow) and nuclear hypertrophy (arrow) in rural stream (R2). e. Cytoplasmic degeneration (*), the picnotic nucleus (arrow), the nucleus in a lateral position (head of arrow) in urban stream (U2). f. Picnotic nucleus (head of arrow) and cytoplasmic vacuolization (*) in rural stream (R2). g. Leukocyte infiltration (arrow) in urban stream (U1). h. Melanomacrophage aggregates (arrows) around the central vein (CV) in urban stream (U2). Stained Hematoxylin Harris and eosin. 


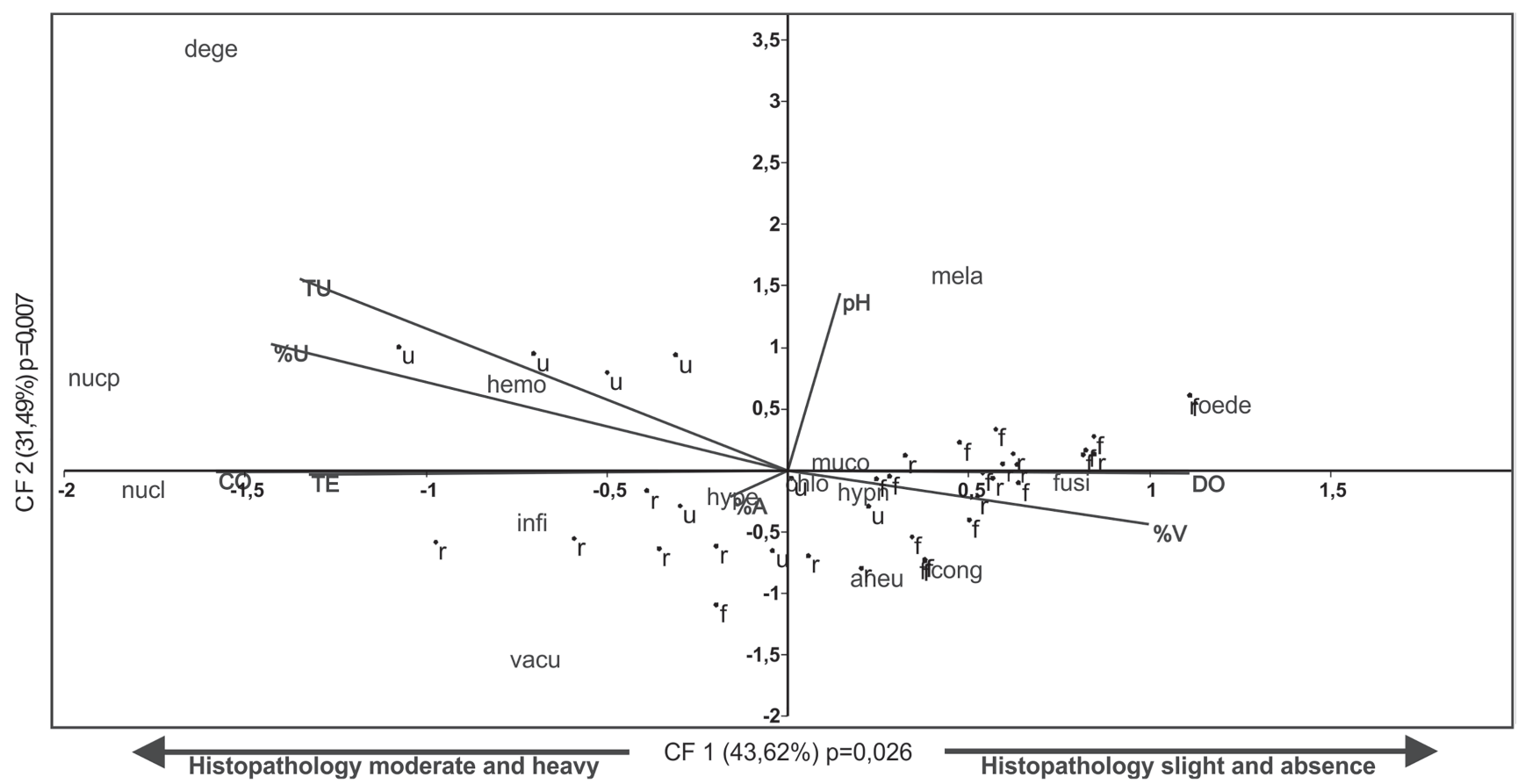

Fig. 4. Canonical correspondence analysis (CCA) applied in all sampling points on the variables of frequency of histopathological alterations of gills and liver and environmental variables. Legend: canonical function (CF), percentage of area with vegetation $(\% \mathrm{~V})$, percentage of agricultural area $(\% \mathrm{~A})$, percentage of urban area $(\% \mathrm{U})$, turbidity (TU), conductivity (CO), temperature (TE), dissolved oxygen (DO), lamellar aneurysm (aneu), partial fusion of lamellae (fusa), lamellar hyperplasia (hipe), lamellar oedema (oede), cytoplasmic degeneration (dege), picnotic nucleus (nucp), nucleus in a lateral position (nucl), leukocyte infiltration (infi), cytoplasmic vacuolation (vacu), vascular congestion (cong), nuclear hypertrophy (hipn), melanomacrophages aggregates (mela), forest (f), rural (r), urban (u).

\section{Discussion}

The evident differences between the frequency and severity of the histopathological alterations found in fish from different streams analyzed validate the use of these biomarkers in the assessment of environmental quality of unmonitored streams. The target organs signal the effects resulting from the action of one or interactions complex mixture of pollutants (Santos et al., 2012).

The higher occurrence and frequency of histopathological alterations such as lamellar oedema, mitochondria-rich cell hyperplasia (MRC) and lamellar aneurysm in fish gills of rural and urban streams demonstrate damage possibly due to the poor quality of the water in these streams. Thus, although we have not conducted analysis of pollutants (pesticides, metals) in the water or sediment, concomitant with the histological analysis, we have indirect evidence of the alarming presence of various contaminants in surface waters of the region (Benatto et al., 2013; Gomes, Barizon, 2014; Nimet et al., 2017). In addition, the use of various insecticides (organophosphates and carbamates) in urban areas, resulting from endemic control programs such as dengue, also adds to the greater input of toxic substances into urban streams (Benatto et al., 2013).

Lamellar oedema occurred in all studied streams, including fish collected in forest streams. This histopathology is considered stage I and does not imply organ involvement, and in some cases it represents a response to natural variations in the environment. This finding corroborates the idea that in environments with better water quality, such as forest stream, the fish presented less severe pathology. The higher frequency of mitochondria-rich cell hyperplasia (MRC) and lamellar aneurysm was observed in streams considered to be more impacted, suggesting the influence of surrounding areas as well as the physical and chemical parameters of these environments on fish health. MRC is a response of the animal to fluctuations in water quality (Reis et al., 2009). A cascade of events resulting from chronic exposure to contaminants leads to loss of the support function of pillar cells (Heath, 1987; Garcia-Santos et al., 2006), which may cause lamellar aneurysm, and in more severe situations lead to disruption of the epithelium and hemorrhage (Poleksic, Mitrovic-Tutundzic, 1994).

The highest $\mathrm{HI}_{\mathrm{G}}$ values, representing histopathological alterations stages I and II in rural and urban streams, indicate moderate damage to the organ. These values may relate to the chronic exposure of fish to stressors in water. The studied streams are located in areas with intensive use of agrochemicals applied to monocrops present in the surroundings. This regional scenario follows the trend reported by Gomes, Barizon (2014), who point out that Brazil is currently the world leader in the use of agrochemicals, 
as well as data from the Health Secretariat of the state of Paraná, which mentions the state of Paraná as the third largest consumer of agrochemicals in Brazil (Benatto et al., 2013). In addition, according to IPARDES (2013) and IBGE (2015), pesticides of the dangerous and very dangerous classes in the evaluated region are the most widely used. In this context, it is suggested that these pesticides reach the streams. This hypothesis, although speculative, gains support, since in the forest streams of the same region, considered as reference in this study, the frequency of these histopathological alterations was significantly lower.

The histopathological alterations in gill occur in an unspecific way, since it is not possible to establish which the responsible physical, chemical or toxic agent was. In this sense, the histopathological alterations in gills observed in this study, mainly stage II in the rural and urban streams, are possibly related to the reduction of the resistance of this tissue under stressful conditions. It should be noted that low levels of dissolved oxygen (DO), higher temperature, electrical conductivity and $\mathrm{pH}$ are closely linked to the conversion of ammonia into the most toxic form (Pereira, Mercante, 2005), which may alter water quality. These physiological changes potentiate the action of possible contaminants present in the aquatic environment, increasing the presence and frequency of histopathological alterations (Freire et al., 2015).

The liver plays functions vital, such as protein synthesis and glycogen storage (Heath, 1987) and is the main detoxification center (Heath, 1987; Hibiya, 1995). Histopathological alterations such as cytoplasmic vacuolation, vascular congestion, nucleus in a lateral position and leukocyte infiltration were the most common in the liver of $A$. bifasciatus, especially in the more human impacted environments. These histopathological alterations in the liver can lead to severe complications to the organism's metabolism (Camargo, Martinez, 2007).

Cytoplasmic vacuolation derives from abnormal lipid metabolism, associated with inhibition of protein synthesis and microtubule breakdown, and at an advanced stage, the nucleus moves to the periphery (Lee et al., 2012). Additionally, the combination of toxic agents with intracytoplasmic lipids may accentuate the formation of these lipid vesicles (Rodrigues, Fanta, 1998). Such histopathology may be related to the poor water quality in streams with greater anthropization of the surrounding area, since it was more frequent in rural and urban environments. The high leukocyte infiltration is an important response to any harmful effect that is occurring in the tissue (Tripathi, Srivastav, 2010). The leukocyte invasion observed in the liver of A. bifasciatus, indicates a relationship with the other histopathological alterations, thus acting as a response of the organism to the presence of liver lesions. Cytoplasmic degeneration leads to loss of polygonal shape of hepatocytes, causing breakdown in cord structure, which can lead to cell degeneration, causing functional and structural damage to liver (Stentiford et al., 2003). This histopathology may indicate dysfunction induced by some noxious agent, once metabolically active areas of the liver are restricted, leading to a possible general reduction in the functions performed by this organ (Teh et al., 1997). The higher frequency of these histopathological alterations only in liver of fish of the U2 stream suggests a poorer water quality in this environment. This hypothesis gains support since cytoplasmic degeneration is a stage II histopathological alteration. If the animal remains in contact with the possible toxic agent, this histopathological alteration can progress to a necrosis, causing irreversibility of the tissue functions (Poleksic, Mitrovic-Tutundzic, 1994).

Higher $\mathrm{HI}_{\mathrm{L}}$ values in fish sampled in rural and urban streams compared to preserved (forest) streams reinforce the effects of different land uses in the surrounding area. These statements corroborate those of Suiçmez et al. (2006) and Hued et al. (2012) who observed liver histopathological alterations in fish exposed to common contaminants in wastewater and agricultural pesticides. Moreover, the higher frequency of histopathological alterations, as well as higher $\mathrm{HI}_{\mathrm{L}}$ in fish collected in urban streams compared to rural ones, may be related to the use of different insecticides to combat Aedes aegypti mosquitoes and chemical weeding (Benatto et al., 2013), as well as the discharge and continuous exposure to other types of pollutants (drugs, heavy metals, petroleum, agrochemicals, detergents and organic matter), frequently present in the urban effluent (IBGE, 2014).

The summarization of the histopathological alterations and their relationship with the environmental variables supports the inference that the effluents from the surroundings of the rural and urban streams interfered in a chronic way with the health of the fish. This hypothesis is supported by the higher occurrence of stages I and II hepatic histopathological alterations in urban streams. It should be emphasized that changes such as presence of lateral nuclei, cytoplasmic vacuolation, picnotic nucleus and cytoplasmic degeneration, which were the most observed in these environments, are considered more serious and impair the functioning of the tissue. The lower relationship of rural streams with moderate and severe histopathological alterations (negative CCA scores) can be explained by the lower frequency with which the possible contaminants are used nearby these streams. This is justified because the most likely source of pollution in these environments is agrochemicals, which are applied discontinuously, following the seasonality and periods of cultivation (soybean and corn) (IPARDES, 2013). Furthermore, the contact of these pesticides with the water bodies is indirect, and probably these substances reach the stream at smaller proportions, especially in those provided with areas of riparian vegetation. On the other hand, urban effluents, especially the storm water, directly and continuously reach the streams, affecting more severely the water quality and the health of fish in these environments. In addition, the urban streams analyzed here are located 
in municipalities that have less than $1 \%$ population served by a sewage system (IBGE, 2014), where the presence of septic tanks or direct disposal contributes in a chronic way to the contamination of the rivers in these urban areas.

A recent study by Yamamoto et al. (2016) correlated the presence of metals and other contaminants in the water and sediment in five cascading reservoirs in the Iguaçu River. The responses of multi-biomarkers (including the presence of metals in muscle and aromatic polycyclic hydrocarbons in the bile) in the same species evaluated here were consistent with a higher level of fish exposure to domestic and industrial effluents from the metropolitan region of Curitiba (upstream), as well as from agricultural areas in reservoirs located further downstream, close to the study area (Yamamoto et al., 2016). In this context, the significant differences between the responses of fish of the forest (control) streams and the others support the evidence that the histological alterations verified here result from the presence of irritants in the water of the streams under intense land uses in the surroundings. Considering the histopathological changes observed, it is important to highlight the problematic and implications of these findings in the context of the conservation of water resources and biota. The studied streams, especially the urban ones, are seriously threatened if no mitigating measures are taken. Changes in the physical and chemical characteristics of the streams resulting from the removal of riparian forests, waterproofing and soil transportation, and exposure to contaminants have the effect of drastically reducing environmental quality. Such environmental change may result in population decline or even local extinction of susceptible species, dominance of opportunistic species, as well as disturbances at various levels of ecosystems (Authman et al., 2015). In this sense, it should be noted that the contaminants present in these streams can even affect human health, either through direct use of water or through bioaccumulation in food webs.

In brief, the more severe histopathological alterations such as lamellar aneurysm, picnotic nucleus, cytoplasmic degeneration and vacuolation observed in fish of rural and urban streams, correlated with the abiotic data evidence the low water quality of these environments, confirming our hypothesis. The health integrity of fish from streams in forest areas of the same region further reinforces the importance of maintaining preservation areas in basins under intensive land uses, especially in the Iguaçu River basin, which presents a relevant endemic fauna.

\section{Acknowledgments}

We thank the Research Group on Fishing Resources and Limnology (GERPEL) for the help in fieldwork and the support of the Western Paraná State University. We also thank all our colleagues for helping in field work and the Hudson M. Munhoz for designed the map. This research was supported by grants from the CAPES.

\section{References}

Agostinho AA, Thomaz SM, Gomes LC. Conservation of the biodiversity of Brazil's inland waters. Conserv Biol [serial on the internet]. 2005; 19(3):646-52. Available from: http://dx.doi. org/ 10.1111/j.1523-1739.2005.00701.x

Authman MMN, Zaki MS, Khallaf EA, Abbas HH. Use of fish as bio-indicator of the effects of heavy metals pollution. J Aquac Res Dev [serial on the internet]. 2015; 6(4):328. Available from: http://dx.doi.org/10.4172/2155-9546.1000328

Ayadi I, Monteiro SM, Regaya I, Coimbra A, Fernandes F, Oliveira MM, Peixoto F, Mnif W. Biochemical and histological changes in the liver and gills of Nile tilapia Oreochromis niloticus exposed to Red 195 dye. RSC Adv [serial on the internet]. 2015; 5(106):87168-78. Available from: http://dx.doi.org/ 10.1039/C5RA13127H

Baumgartner G, Pavanelli CS, Baumgartner D, Bifi AG, Debona T, Frana VA. Peixes do baixo rio Iguaçu. Maringá: EDUEM; 2012.

Benatto A, Rubio C, Jesus DA, Goto DYN, Rubio G, Belmonte I et $a l$, organizadores. Vigilância da saúde de populações expostas a agrotóxicos no Paraná. Curitiba: Secretaria do estado da saúde do Paraná (SESA); 2013.

Camargo MMP, Martinez CBR. Histopathology of gills, kidney and liver of a Neotropical fish caged in an urban stream. Neotrop Ichthyol [serial on the internet]. 2007; 5(3):327-36. Available from: http://dx.doi.org/10.1590/S1679-62252007000300013

Cerqueira CCC, Fernandes MN. Gill tissue recovery after copper exposure and blood parameter responses in the Tropical Fish Prochilodus scrofa. Ecotoxicol Environ Saf [serial on the internet]. 2002; 52(2):83-91. Available from: http://dx.doi. org/10.1006/eesa.2002.2164

Dane H, Sisman T. Histopathological changes in gill and liver of Capoeta capoeta living in the Karasu River, Erzurum Environ Toxicol [serial on the internet]. 2015; 30(8):904-17. Available from: http://dx.doi.org/10.1002/tox.21965

Delariva RL, Hahn NS, Kashiwaqui EA. Diet and trophic structure of the fish fauna in a subtropical ecosystem: impoundment effects. Neotrop Ichthyol [serial on the internet]. 2013; 11(4):891-904. Available from: http://dx.doi.org/10.1590/ S1679-62252013000400017

Freire CA, Souza-Bastos LR, Chiesse J, Tincani FH, Piancini LDS, Randi MAF et al. A multibiomarker evaluation of urban, industrial, and agricultural exposure of small characins in a large freshwater basin in southern Brazil. Environ Sci Pollut Res [serial on the internet]. 2015; 22(17):13263-77. Available from: http://dx.doi.org/10.1007/s11356-015-4585-5

Garcia-Santos S, Fontaínhas-Fernandes A, Wilson JM. Cadmium tolerance in the Nile tilapia (Oreochromis niloticus) following acute exposure: assessment of some ionoregulatory parameters. Environ Toxicol [serial on the internet]. 2006; 21(1):33-46. Available from: http://dx.doi.org/10.1002/tox.20152

Gomes MAF, Barizon RRM. Panorama da contaminação ambiental por agrotóxicos e nitrato de origem agrícola no Brasil: cenário 1992/2011. Jaguariúna: Embrapa Meio Ambiente; 2014. (Documentos/Embrapa Meio Ambiente; 98). 
Gomes ID, Nascimento AA, Sales A, Araújo FG. Can fish fill anomalies be used to assess water quality in freshwater Neotropical systems? Environ Monit Assess [serial on the internet]. 2012; 184(9):5523-31. Available from: http://dx.doi. org/10.1007/s10661-011-2358-2

Gotelli NJ, Ellison AM. Princípios de estatística em ecologia. Porto Alegre: Artmed; 2011.

Hammer ØA, Harper DAT, Ryan PD. PAST: Paleontological statistics software package for education and data analysis. Paleontol Electronica. 2001; 4(1):1-9.

Hauser-Davis RA, Lavandier RC, Bastos FF, Oliveira TF, Oliveira Ribeiro CA, Ziolli RL, Campos RC. Alterations in morphometric and organosomatic indices and histopathological analyses indicative of environmental contamination in mullet, Mugil liza, from Southeastern Brazil. Bull Environ Contam Toxicol [serial on the internet]. 2012; 89(6):1154-60. Available from: http://dx.doi.org/10.1007/s00128-012-0846-x

Heath AG. Water pollution and fish physiology. Boca Raton: CRC Press; 1987.

Hibiya T. An atlas of fish histology: normal and pathological features. 2nd ed. Tokyo: Kodansha; 1995.

Hued AC, Oberhofer S, Bistoni MA. Exposure to a commercial glyphosate formulation $\left(\right.$ Roundup $\left.^{\circledR}\right)$ alters normal gill and liver histology and affects male sexual activity of Jenynsia multidentata (Anablepidae, Cyprinodontiformes). Arch Environ Contam Toxicol [serial on the internet]. 2012; 62(1):107-17. Available from: http://dx.doi.org/10.1007/s00244-011-9686-7

Instituto Paranaense de Desenvolvimento Econômico e Social (IPARDES). Indicadores de desenvolvimento sustentável por bacias hidrográficas do estado do Paraná. Curitiba: IPARDES; 2013.

Instituto Brasileiro de Geografia e Estatística (IBGE). Cidades do Paraná. [Internet]. 2014 [Updated 2017 Jun]. Available from: http://www.cidades.ibge.gov.br/xtras/perfil.php?lang= ecodmun $=410500$ esearch $=$ parana $\mid$ catanduvas $\mid$ infograficos:informacoes-completas

Instituto Brasileiro de Geografia e Estatística (IBGE)/ Coordenação de Recursos Naturais e Estudos Ambientais e Coordenação de Geografia. Indicadores de desenvolvimento sustentável: Brasil.. Rio de Janeiro: IBGE; 2015. (Estudos e pesquisas; Informação geográfica; No. 10).

Lee JW, Kim JW, Riu ND, Moniello G, Hung SSO. Histopathological alterations of juvenile green (Acipenser medirostris) and white sturgeon (Acipenser transmontanus) exposed to graded levels of dietary methylmercury. Aquat Toxicol [serial on the internet]. 2012; 109:90-99. Available from: http://dx.doi.org/10.1016/j. aquatox.2011.12.008

Legendre P, Legendre L. Numerical Ecology. 2nd ed. Amsterdam: Elsevier; 1998.

Lins JAPN, Kirschnik PG, Queiroz VS, Cirio SM. Use of fish as biomarkers for monitoring aquatic environment. Revista Acadêmica: Ciência Animal. 2010; 8(4):469-84.

Miranda JC. Ameaças aos peixes de riachos da Mata Atlântica. Natureza Online [serial on the internet]. 2012; 10(3):136-39. Available from: http://www.naturezaonline.com.br/natureza/ conteudo/pdf/07_MirandaJC_136139.pdf
Montes CS, Ferreira MAP, Santos SSD, Rocha RM. Environmental quality of an estuary in Amazon delta using immunohistochemical and porphological analyses of gill as biomarkers. Acta Sci Biol Sci [serial on the internet]. 2015; 37(1):113-21. Available from: http://dx.doi.org/10.4025/ actascibiolsci.v37i1.24541

Nimet J, Guimarães ATB, Delariva RL. Use of muscular cholinesterase of Astyanax bifasciatus (Teleostei, Characidae) as a biomarker in biomonitoring of rural streams. Bull Environ Contam Toxicol [serial on the internet]. 2017; 99(2):232-38. Available from: http://dx.doi.org/10.1007/s00128-017-2111-9

Nogueira C, Buckup PA, Menezes NA, Oyakawa OT, Kasecker TP, Neto MBR, Silva JMCD. Restricted-range fishes and the conservation of Brazilian freshwaters. PloS ONE [serial on the internet]. 2010; 5(6):e11390. Available from: http://dx.doi. org/10.1371/journal.pone.0011390

van der Oost R, Beyer J, Vermeulen NPE. Fish bioaccumulation and biomarkers in environmental risk assessment: a review. Environ Toxicol Pharmacol [serial on the internet]. 2003; 13(2):57-149. Available from: http://dx.doi.org/10.1016/ S1382-6689(02)00126-6

Paulino MG, Benze TP, Sadauskas-Henrique H, Sakuraqui MM, Fernandes JB, Fernandes MN. The impact of organochlorines and metals on wild fish living in a tropical hydroelectric reservoir: bioaccumulation and histopathological biomarkers. Sci Total Environ [serial on the internet]. 2014; 497487:293-306. Available from: http://dx.doi.org/10.1016/j. scitotenv.2014.07.122

Pereira LPF, Mercante CTJ. Ammonia in fish breedings systems and its effects on the water quality - a review. Bol Inst Pesca [serial on the internet]. 2005; 31(1):81-88. Available from: http://www.pesca.agricultura.sp.gov.br/Pereira_31_1.pdf

Pereira MCB, Scroccaro JL, organizadores. Bacias hidrográficas do Paraná: Série Histórica. Curitiba: Secretaria de Meio Ambiente e Recursos Hídricos (SEMA) - Paraná; 2010.

Poleksic V, Mitrovic-Tutundzic V. Fish gills as a monitor of sublethal and chronic effects of pollution. In: Müller R, Lloyd $\mathrm{R}$, editors. Sublethal and chronic effects of pollutants on freshwater fish. Oxford: Fishing News Books; 1994. p.339352.

Reis AB, Sant'Ana DMG, Azevedo JF, Merlini LS, Araújo EJA. The influence of the aquatic environment in tanks sequentially interconnected with PVC pipes on the gill epithelium and lamellas of tilapia (Oreochromis niloticus). Pesqui Vet Bras [serial on the internet]. 2009; 29(4):303-311. Available from: http://dx.doi.org/10.1590/S0100-736X2009000400005

Rodrigues EL, Fanta E. Liver histopathology of the fish Brachydanio rerio after acute exposure to sublethal levels of the organophosphate Dimetoato 500. Rev Bras Zool. 1998; 15(2):441-50.

Santos DMS, Cruz CF, Pereira DP, Alves LMC, Moraes FR. Microbiological water quality and gill histopathology of fish from fish farming in Itapecuru-Mirim County, Maranhão State. Acta Sci Biolo Sci [serial on the internet]. 2012; 34(2):199205. Available from: http://dx.doi.org/10.4025/actascibiolsci. v34i2.8460 
Silva MR, Campos ACE, Bohm FZ. Agrotóxicos e seus impactos sobre ecossistemas aquáticos continentais. SaBios - Revista de Saúde e Biologia [serial on the internet]. 2013; 8(2):46-58. Available from: http://revista.grupointegrado.br/revista/index. php/sabios2/article/view/899/519

Statsoft, Inc. STATISTICA [Data Analysis Software System], version 7.0. Available from: http://www.statsoft.com.

Stentiford GD, Longshaw M, Lyons BP, Jones G, Green M, Feist SW. Histopathological biomarkers in estuarine fish species for the assessment of biological effects of contaminants. Mar Environ Res [serial on the internet]. 2003; 55(2):137-59. Available from: http://dx.doi.org/10.1016/S0141-1136(02)00212-X

Strahler AN. Quantitative analysis of watershed geomorphology. Am Geophys Union. 1957; 38(6):913-20.

Suiçmez M, Kayım M, Köseoğlu D, Hasdemir E. Toxic effects of lead on the liver and gills of Oncorhynchus mykiss WALBAUM 1792. Bull Environ Contam Toxicol [serial on the internet]. 2006; 77(4):551-58. Available from: http://dx.doi.org/10.1007/ s00128-006-1099-3

Teh SJ, Adams SM, Hinton DE. Histopathologic biomarkers in feral freshwater fish populations exposed to different types of contaminant stress. Aquat Toxicol [serial on the internet]. 1997; 37(1):51-70. Available from: http://dx.doi.org/10.1016/ S0166-445X(96)00808-9
Tripathi S, Srivastav AK. Liver profile of rats after long-term ingestion of different doses of chorpyrifos. Pestic Biochem Physiol [serial on the internet]. 2010; 97(1):60-65. Available from: http://dx.doi.org/10.1016/j.pestbp.2009.12.005

Troncoso IC, Cazenave J, Bacchetta C, Bistoni MA. Histopathological changes in the gills and liver of Prochilodus lineatus from the Salado River basin (Santa Fe, Argentina). Fish Physiol Biochem [serial on the internet]. 2012; 38(3):693702. Available from: http://dx.doi.org/10.1007/s10695-0119551-7

Yamamoto FY, Pereira MVM, Lottermann E, Santos GS, Stremel TR, Doria HB et al. Bioavailability of pollutants sets risk exposure to biota and human population in reservoirs from Iguaçu River (Southern Brazil). Environ Sci Pollut Res [serial on the internet]. 2016; 23(18):18111-28. Available from: http:// dx.doi.org/10.1007/s11356-016-6924-6 
